\title{
Elektros energijos gamybos technologijų darnumo vertinimas, taikant integruotus rodiklius
}

Dalia Štreimikienė,

Asta Mikalauskienè,

Jūratė Zaikienè

Lietuvos energetikos institutas, Breslaujos g. 3,

LT-44403 Kaunas

El.paštas:dalia@mail.lei.lt
Analizuojami elektros energijos gamybos technologiju darnumo vertinimo klausimai. Straipsnyje atliktas elektros energijos gamybos technologijų darnumo vertinimas Europos Sajungoje (ES), remiantis daugiakriteriniais analizès metodais. Darnumo vertinimui pritaikyti integruoti technologijų darnumo rodikliai, leidžiantys ịvertinti elektros energijos gamybos technologijas pagal socialinius, aplinkosauginius ir ekonominius darnumo vertinimo rodiklius ir kiekvienai technologijai suteikti vieną įvertị bei suskirstyti elektros energijos gamybos technologijas pagal jų indèli igyvendinant darnaus energetikos vystymosi tikslus ES. Elektros energijos gamybos technologijų vertinimui ES panaudoti ES atliktų empirinių studijų rezultatai. Tyrimas parodè, kad pažangiausios elektros energijos gamybos technologijos yra paremtos atsinaujinančiaisiais energijos ištekliais.

\section{IVADAS}

Didejjanti Europos priklausomybè nuo energijos importo, klimato kaita bei energijos kainų augimas vis dažniau verčia diskutuoti apie alternatyvas energetiniame sektoriuje. Darnaus vystymosi igyvendinimas tampa aiškiu energetikos prioritetu pasaulyje. Žinoma, kad ekonominiam ir socialiniam vystymuisi labai svarbus saugus ir patikimas energijos tiekimas priimtinomis ir stabiliomis kainomis - tai turètų tapti neatsiejama moksliškai pagrịstos ir nuoseklios energijos politikos dalimi. Todèl bendra Europos energetikos politika tampa strateginès svarbos dalyku. Darnios energetikos sistemos yra reali siekiamybè, tačiau daugybẻ klausimų turi būti neatidèliotinai sprendžiami, kad šis darnumas būtų pasiektas.

Kad energetikos politika ịneštų savo indèlị ị darnų vystymąsi, reikia sukurti glaudesnes energetikos politikos, aplinkos apsaugos ir mokslinių tyrimų politikos sąsajas. Svarbiausia yra pagrịsti ịvairius energetikos plètros ir valstybės vykdomos politikos sprendimus bei juos harmonizuoti, remiantis darnaus vystymosi koncepcija. Daugelis igyvendinamų valstybės politikos priemonių, siekdamos konkrečių tikslų, daro neigiamą poveikị kitiems strateginiams šalies prioritetams, ir igyvendinamos politikos dažnai viena kitai prieštarauja. Taigi labai svarbus klausimas yra energetikos ir aplinkos politikų harmonizavimas, būtinas priimant konkrečius sprendimus dèl energetikos sektoriaus plètros.
Keliami tikslai energetikos sektoriuje, priimant sprendimus, yra daugialypiai ir konfliktuoja tarpusavyje: minimizuoti kaštus, poveiki aplinkai, užtikrinti energijos tiekimo patikimumą ir kt. Todèl priimant strateginius sprendimus dèl energetikos sektoriaus plètros būtina taikyti daugiakriterinę analizę arba daugiakriterinị vertinimą, leidžiantị ịvertinti reliatyvią kriterijų svarbą sprendimus priimančiam asmeniui, kai yra derinami ekonominiai, aplinkosauginiai, socialiniai ir kt. kriterijai, bei parinkti tinkamiausią sprendimą atsižvelgiant ị visus kriterijus. Taigi daugiakriteriniai vertinimo arba sprendimų prièmimo metodai yra bandymas vienu metu vertinti kelis alternatyvius sprendimus pagal keletą vienas kitam prieštaraujančių kriterijų. Priimant sprendimus energetikos sektoriuje dažnai susiduriama su skirtingų interesų grupèmis, skirtingais tikslais ir skirtingomis informacijos rūšimis. Tai paaiškina, kodèl daugiakriteriniai vertinimo metodai priimant sprendimus svarbiais energetikos plètros klausimais tampa vis populiaresni.

Sprendimai energetikos sektoriuje apima tiek sprendimus, susijusius su energetikos sektoriaus plètros scenarijais arba strateginių šalies energetikos plètros prioritetų nustatymu (makrolygmuo), tiek su sprendimais dèl konkrečių energijos gamybos technologijų parinkimo arba dèl konkrečių energetikos projektų igyvendinimo (mikrolygmuo). Analizuojant sprendimų alternatyvas skirtinguose lygmenyse labai svarbu parinkti tinkamus alternatyvų vertinimo kriterijus 
bei jų kiekybinio vertinimo rodiklius. Sprendimų paramos sistemoms sudaryti taikomi sprendimų prièmimo metodai. Taigi planuotojams ir sprendimų prièmëjams energetikos sektoriuje tenka spręsti sudètingus klausimus - kokius energijos nešèjus bei energijos konversijos technologijas panaudoti arba kaip apjungti įvairius energijos išteklius su įvairiomis technologijomis, kad geriausiai užtikrintų dabartinius ir ateities energijos poreikius? Siekiant pagrịsti šiuos sprendimus taikomi daugiakriteriniai sprendimų paramos modeliai.

Vienas svarbiausių sprendimų energetikos sektoriuje yra tinkamiausių elektros energijos gamybos technologijų parinkimas. Šios problemos sprendimui taikoma keletas alternatyvų rangavimo metodikų [1]. Šios grupès uždavinių pagrindinis tikslas yra nustatyti prioritetines energijos gamybos technologijų alternatyvas, vèliau parengti energetikos sektoriaus plètros planus bei parinkti politikos priemones, skirtas šių technologijų skverbimuisi į rinką paskatinti. Daugelis straipsnių bei studijų, skirtų šio tipo uždavinių grupei nagrinèti, daugiausia dèmesio skyrè branduolinès energijos palyginimui su tradiciniais energijos gamybos šaltiniais arba su atsinaujinančiaisiais energijos šaltiniais [2-6]. Šių studijų tikslas buvo greičiau sukurti metodus problemai spręsti, o ne rasti atsaką, kuri technologija yra geriausia, nes problemos sprendimui turèjo būti atliktos suinteresuotųjų šalių apklausos, siekiant nustatyti, kuriems kriterijams, ranguojant technologijas, daugiausia svarbos skiria visuomenès grupès. Devintojo dešimtmečio pabaigoje dèl perdètos rizikos priskyrimo atominei energetikai ir klimato kaitos problemų aštrèjimo buvo atlikta keletas studijų, skirtų elektros energijos technologijų rangavimui pagal tam tikrus energetikos politikos nulemtus kriterijus, siekiant pagrịsti atsinaujinančiųjų energijos išteklių panaudojimo plètrą [7-10].

Daugiakriteriniai vertinimo metodai pastaruoju metu plačiai taikomi darnumo vertinimui. Darnumo vertinimo metodus galima suskirstyti $i$ keturias pagrindines grupes: rodikliai ir indikatoriai, darnumo vertinimo instrumentai produktų (gamybos būdų) lygmenyje, projektų bei šalies lygmenyse [11]. Pirmąją grupę įrankių darnumui vertinti sudaro rodikliai. Rodikliai yra paprastas įrankis, leidžiantis įvertinti ekonominius, socialinius ir aplinkosauginius šalies pletros tikslus. Jeigu aplinkosauginiai, socialiniai ir ekonominiai rodikliai yra integruoti ị vieną rodiklį, tai jie sudaro indeksą. Rodikliai turi pasižymèti tokiomis savybėmis: paprastumas, plati aprẻptis, kiekybinio ịvertinimo galimybè, leidžianti nustatyti tendencijas.

Straipsnio tikslas - ivertinti elektros energijos gamybos technologijų darnumą ES, remiantis prioritetiniais energetikos ir aplinkos politikos tikslais. Siekiant nurodyto darbo tikslo, yra iškeliami šie uždaviniai:

- išanalizuoti energetikos ir aplinkos politikos prioritetinius tikslus ir nustatyti elektros energijos technologiju darnumo vertinimo kriterijus;

- remiantis elektros energijos gamybos technologijų darnumo vertinimo kriterijais parinkti technologijų darnu- mo rodiklius, leidžiančius palyginti ir suranguoti elektros energijos gamybos technologijas pagal jų teigiamą ittaką darniai energetikos plètrai;

- ívertinti elektros energijos gamybos technologiju darnumą, apskaičiuojant technologijų darnumo rodiklius konkrečioms elektros energijos gamybos technologijoms, remiantis empirinių studijų, atliktų ES, rezultatais;

- suskirstyti elektros energijos gamybos technologijas pagal jų teigiamą įtaką, igyvendinant darnios energetikos plètros prioritetus.

\section{ELEKTROS ENERGIJOS GAMYBOS TECHNOLOGIJU DARNUMO VERTINIMO KRITERIJAI}

Energijos gamybos technologijų darnumo vertinimas ir skirstymas pagal tai, kaip jos užtikrina prioritetinius energetikos politikos tikslus, yra svarbus parengtos daugiakriterinių sprendimų paramos energetikos sektoriuje metodikos aspektas. Planuojant elektros energetikos sektoriaus plètrą, rengiant energetikos sektoriaus plètros scenarijus bei parenkant ateities elektros generavimo technologijas labai svarbu nustatyti perspektyviausias elektros energijos gamybos technologijas, leisiančias mažiausiomis sąnaudomis užtikrinti energetikos politikos prioritetinius tikslus. Nustačius tokias technologijas, pirmiausia jas galima įtraukti i elektros energetikos plètros planus bei parinkti klimato kaitos švelninimo ir kitas politikos priemones, skatinančias šiu technologijų skverbimąsi i elektros rinkas. Toliau pateiktas elektros generavimo technologijų vertinimo ir skirstymo, taikant integruotus darnumo indikatorius, pavyzdys leis nustatyti elektros energijos gamybos technologijas, geriausiai atitinkančias energetikos politikoje nustatytus prioritetinius tikslus.

Europos Komisijos 2007 m. sausi parengtu komunikatu Europos energetikos politika Europos valstybès skatinamos imtis veiksmų ir igyvendinti darnios, konkurencingos ir saugios energetikos principus. Pagrindiniai tikslai:

- suformuoti naująją Europos energetikos politiką, kuri turi būti ambicinga, ilgalaikè ir naudinga visiems europiečiams;

- iki $2020 \mathrm{~m}$. bent $20 \%$, palyginti su $1990 \mathrm{~m}$., sumažinti i atmosferą išskiriamų šiltnamio reiškini sukeliančių dujų kiekị ir užkirsti kelią klimato kaitai;

- sumažinti ES pažeidžiamumą dèl didèjančio dujų ir naftos importo iš kitų šalių;

- skatinti ekonomikos augimą ir naujų darbo vietų kūrimą, užtikrinant energijos priimtinomis kainomis tiekimą vartotojams;

- iki $2020 \mathrm{~m}$. atsinaujinančiųjų energijos išteklių dalị visos ES suvartojamos pirminès energijos struktūroje padidinti iki $20 \%$;

- iki $2020 \mathrm{~m}$. igyvendinti energijos vartojimo efektyvumo didinimo veiksmų planą ir sumažinti energijos sąnaudas $20 \%$; 
- $\quad$ iki 2020 m. bent trečdalị visos ES elektros energijos pagaminti naudojant atsinaujinančiuosius energijos išteklius;

- skatinti biokuro gamybą ir naudojimą, siekti, kad $2020 \mathrm{~m}$. biokuro dalis sudarytų $10 \%$ visų transporto priemonių sunaudojamų degalų kiekio.

Remiantis ES energetikos politikos prioritetiniais tikslais formuojama rodiklių sistema socialiniams ekonominiams ir aplinkosauginiams energijos gamybos technologijų darnumo vertinimo kriterijams išreikšti (1 lentelè). Dauguma 1 lenteleje pateiktų rodiklių buvo įvertinti bei panaudoti kai kuriuose ES projektuose, todèl paskutiniame lentelès stulpelyje yra pateikti duomenų šaltiniai, panaudoti rodikliams įvertinti.

\section{ELEKTROS ENERGIJOS GAMYBOS TECHNOLOGIJŲ DARNUMO VERTINIMO RODIKLIAI}

Elektros energijos gamybos technologijų vertinimo rodikliai, parinkti svarbiausiems ES energetikos politikos tikslams atspindèti, yra vertinami taikant gyvavimo ciklo metodiką (angl. LCA). LCA metodas remiasi holistiniu ịvertinimu viso energijos ir medžiagų srauto, susijusio su tam tikra sistema ar procesu, t. y. ịvertinimui naudojamas platesnis požiūris, apimantis ne tik su technologijos procesu susijusius poveikius, bet ir kuro iškasimą, transportavimą ir kuro bei kitų medžiagų paruošimą, jejgainès statymą, atliekų sutvarkymą ir jẻgainès sustabdymą.

Ekonominiai rodikliai. Ekonominè elektros energijos gamybos technologijų darnumo vertinimo dimensija yra labai svarbi, nes energijos tiekimo kaštai yra pagrindinis veiksnys, lemiantis technologijos įsiskverbimą ị rinkas. Elektros energijos gamybos technologijų vertinimui yra parinkti 5 rodik- liai: privatūs kaštai, vidutinė apkrova, prijungimo prie tinklo kaštai, atsakas i pikinę apkrovą, tiekimo patikimumas. Ne visi vertinimo rodikliai yra vienodai svarbūs. Svarbiausiais rodikliais galima laikyti privačius kaštus, apkrovos veiksnị bei prijungimo prie tinklo kaštus.

Privatūs kaštai, išreikšti EURct / $k W h$, remiasi vidutinių pasvertų elektros energijos generavimo kaštų metodologija. Pagal šią Tarptautinès energetikos agentūros (TEA) sukurtą metodiką, generavimo kaštai yra įvertinti, remiantis grynąja elektra, patiekta ị tinklą, ir išlaidų diskontavimu i jų dabartinę grynąją vertę 2005 m. Šie metai parinkti kaip baziniai, taikant $5 \%$ diskonto koeficientą.

Taigi vidutiniai pasverti gyvavimo ciklo kaštai GWh pagamintos elektros energijos yra ịvertinami pagal (1) formulę:

$$
A L L G C=\sum_{t=o}^{T} \frac{\left[I_{t}+M_{t}+F_{t}\right]}{(1+r)^{t}} / \sum_{t=0}^{T} \frac{\left[E_{t}\right]}{(1+r)^{t}} ;
$$

čia $I_{t}$ - investicinès išlaidos $t$ metais; $M_{t}$ - eksploatacijos ir priežiūros kaštai $t$ metais; $F t$ - išlaidos kurui $t$ metais; $E_{t}$ - elektros energijos generavimas $t$ metais; $r$ - diskonto koeficientas.

Investicinès išlaidos kiekvienais metais apima statybos, atnaujinimo ir uždarymo išlaidas. Pagal TEA metodiką, statybos kaštai yra ịvertinti taip, lyg jègainẻ būtų pastatyta per vieną naktį (angl. overnight costs). Eksploatacijos ir priežiūros kaštai sudaro nedidelę visų kaštų dalį. Fiksuoti eksploatacijos ir priežiūros kaštai apima personalo kaštus, draudimą, mokesčius ir kt. Kintantys eksploatacijos ir priežiūros kaštai apima įrenginių priežiūros ir remonto kaštus, medžiagų kaštus, atliekų šalinimo (dirbant normaliu režimu) kaštus ir kt. (išskyrus radioaktyviųjų atliekų laidojimo kaštus).

1 lentelè. Elektros energijos gamybos technologijų darnumo vertinimo rodikliai

\begin{tabular}{|c|c|c|c|}
\hline Žymèjimas & Rodiklis & Matavimo vienetas & $\begin{array}{c}\text { Informacijos ir } \\
\text { duomenų šaltiniai }\end{array}$ \\
\hline \multicolumn{4}{|c|}{ Ekonominiai kriterijai } \\
\hline PRIVATŪS KAŠTAI & $\begin{array}{c}\text { Privatūs kaštai } \\
\text { (investicijos ir operaciniai kaštai) }\end{array}$ & EURct/kWh & ES 6BP projektas CASES \\
\hline APKROVA & Vidutinis apkrovos arba patikimumo faktorius & $\%$ & ES 6BP projektas EUSUSTEL \\
\hline SAUGUMAS & Tiekimo saugumas & Balai $(0-5)$ & ES 7BP projektas NEEDS \\
\hline TINKLO KAŠTAI & Prijungimo prie tinklo kaštai & Balai $(0-5)$ & ES 6BP projektas CASES \\
\hline PIKINĖ APKROVA & Pikinės apkrovos atsakas & Balai $(0-5)$ & ES 7BP projektas NEEDS \\
\hline \multicolumn{4}{|c|}{ Aplinkosauginiai kriterijai } \\
\hline $\mathrm{CO}_{2}$-eq & ŠD emisijos & $\mathrm{kg} / \mathrm{kWh}$ & ES BP 6 projektas CASES \\
\hline APLINKA & Aplinkosauginiai išoriniai kaštai & EURct/kWh & ES 6BP projektas CASES \\
\hline RADIACIJA & Radionuklidų išoriniai kaštai & EURct/kWh & ES 6BP projektas CASES \\
\hline SVEIKATA & Poveikio žmogaus sveikatai išoriniai kaštai & EURct/kWh & ES 6BP projektas CASES \\
\hline \multicolumn{4}{|c|}{ Socialiniai kriterijai } \\
\hline UŽIMTUMAS & $\begin{array}{l}\text { Technologijos suteikiamos } \\
\text { ¿darbinimo galimybès }\end{array}$ & Žmogaus metai/kWh & PSI Ecoinvent bazè \\
\hline MAISTO RIZIKA & Maisto tiekimo rizika & Balai $(0-5)$ & ES 6BP projektas CASES \\
\hline INCID PRAEITYJE & Incidentai praeityje & Incidentai/kWh & PSI Ecoinvent bazė \\
\hline INCID ATEITYJE & Incidentai ateityje & Balai (0-5) & ES 7BP projektas NEEDS \\
\hline
\end{tabular}


Kuro kainos yra įvertintos, remiantis ES projektu EUSUSTEL [12]. Techninis jègainių tarnavimo laikas yra ịvertintas taip pat remiantis EUSUSTEL projekto rezultatais. Vertinant TE bei véjo ar saulès jẻgainių elektros energijos gamybos kaštus buvo atlikti papildomi ịvertinimai, tokie kaip TE gaminamos šiluminès energijos kaštai bei rezervinių galių kaštai, būtini saulès, vejo ir vandens jègainèms. Visi kaštai ịvertinti be mokesčių, siekiant išvengti iškraipymų. Praktiškai visose ES atliktose energijos gamybos technologijų vertinimo studijose (EUSUSTEL [12], CASES [13, 14], NEEDS [15-17], PLANETS $[18,19]$ ir kt.) buvo pavartotas šis rodiklis. ES studijose elektros energijos gamybos technologiju vertinimui šioje ataskaitoje panaudoti ES vidutiniai pasverti elektros energijos generavimo kaštai $2020 \mathrm{~m}$.

Prijungimo prie tinklo kaštai (0-5 balai) yra kokybinis rodiklis, atspindintis prijungimo prie tinklo kaštus, nes privatūs kaštai jų neịvertina, o tai yra svarbus ekonominis rodiklis, vertinant elektros energijos gamybos technologijas. Kadangi elektros energiją gaminančios jègainès pasižymi skirtingais prijungimo prie tinklo kaštais, pvz., vèjo jègainės jūroje turi labai aukštus prijungimo prie tinklo kaštus, šis rodiklis bus ivertintas balais. Kuo didesnis yra vertinimo balas, tuo didesnẻ aukštų prijungimo prie tinklo kaštų rizika. Šis rodiklis buvo panaudotas ES BP 6 projekte CASES $[13,14]$.

Atsakas įpikinęapkrova (0-5 balai) yra kokybinis rodiklis, atspindintis greitą technologijos reagavimą ị didelę trumpalaikę poreikio kaitą. Ši technologijų savybè labai patraukli esant liberalizuotai elektros rinkai. Bazinès apkrovos technologijos bei atsinaujinančiuosius energijos išteklius naudojančios technologijos, kurios labai priklauso nuo klimato sąlygų, tokios kaip vejo ar hidroelektrinès, nepasižymi šia teigiama savybe ir pagal šitą kokybinị rodiklị vertinamos labai mažu balu. Šis rodiklis buvo pritaikytas daugelyje ES šaliu atliktų energijos gamybos technologijų vertinimo studijų (NEEDS [15-17], GaBE [19], CASES [13, 14], PLANETS [18]). Analizuojant minètas studijas pastebèta, kad technologijų vertinimui pagal šị kokybinį kriterijų taikomos labai ịvairios balų skalès. GaBE studijoje (0-100), NEEDS [15] projekte (1-10), PLANETS [18] projekte (0-5).

Vidutinis apkrovos veiksnys, išreikštas \%, išmatuoja atskirų technologijų vidutinę apkrovą per metus. Šis rodiklis

2 lentelè. Elektros energijos gamybos technologijų atsako i pikinę apkrovą vertinimas [18]

\begin{tabular}{cc}
\hline Energijos rūšis & Balas \\
\hline Atominè energija & 0,5 \\
\hline Kuro elementai & 0,5 \\
\hline Anglys & 2,5 \\
\hline Lignitas & 1 \\
\hline Mazutas & 5 \\
\hline Gamtinès dujos & 5 \\
\hline Hidroelektrinè & 1,5 \\
\hline Biomasès jègainè & 5 \\
\hline Saulès fotoelektra & 0 \\
\hline Vèjo jègainè & 0
\end{tabular}

buvo taikomas EUSUSTEL [12], NEEDS [16], GaBE [19] ir PLANETS [18] projektuose, vertinant energijos gamybos technologijas. Elektros energijos gamybos technologiju vertinimui šioje ataskaitoje panaudotos vidutinès rodiklių reikšmès ES $2020 \mathrm{~m}$.

Tiekimo saugumo rodiklis ( $0-5$ balai) yra labai svarbus, siekiant atspindèti ES energetikos politikos prioritetinę krypti - energetinę nepriklausomybę. Tiekimo saugumas elektros energijos tiekime gali būti vertinamas kaip ilgalaikè nepriklausomybe nuo energijos tiekimo iš užsienio arba elektros energijos gamybos autonomijos laipsnis. Šis rodiklis buvo pritaikytas NEEDS [16] ir PLANETS [18] projektuose. Vertinimas balais priklauso nuo to, ar kuras, naudojamas elektros energijos gamybai, yra importuojamas ar vietinis, ar jo atsargos yra baigtinès ar ne. Technologijų vertinimas pagal naudojamą kurą ir elektros energijos gamybos autonomiją pateiktas 3 lentelèje.

Aplinkosauginiai rodikliai. Pagrindiniai keturi aplinkosauginiai rodikliai elektros energijos gamybos technologiju vertinimui yra: ŠD emisijos, aplinkosauginiai išoriniai kaštai, išoriniai poveikio žmogaus sveikatai kaštai, išoriniai radionuklidų kaštai. Visi aplinkosauginiai rodikliai yra ịvertinti taikant LCA metodologiją ir ịvertina viso kuro ciklo ŠD emisijas bei išorinius kaštus.

$\check{S}$ D emisijos, išreikštos $\mathrm{kg}\left(\mathrm{CO}_{2}\right.$-eq. $) / \mathrm{kWh}$, yra vienas svarbiausių aplinkosauginių rodiklių vertinant elektros energijos gamybos technologijas. Šis rodiklis pavartotas vietoje išorinių ŠD emisijų kaštų dèl to, kad išorinių kaštų dèl klimato kaitos vertinimai pasižymi dideliu neapibrèžtumu. Šis rodiklis buvo pritaikytas visose ES studijose, skirtose energijos gamybos technologiju vertinimams. Elektros energijos gamybos technologijų vertinimui šioje atskaitoje panaudotos vidutinès rodiklio reikšmès ES $2020 \mathrm{~m}$.

Aplinkosauginiai išoriniai kaštai, išreikšti EURct / $k W h$, atspindi žalą ekosistemoms dèl kietųjų dalelių, dujų ir kitų teršalų emisijos į atmosferą, dirvą ir vandeni. Šie kaštai buvo ivvertinti tokių ES BP projektų kaip ExternE [20], NEEDS [16] ir CASES [13] metu bei panaudoti daugelyje kitų energijos gamybos technologijas analizuojančiu projektų. Aplinkosauginiai išoriniai kaštai yra apskaičiuoti piniginiais vienetais, ivvertinus teršalų neigiamą ịtaką pasèliams, medžiagoms bei bioịvairovès nuostolius dèl rūgštèjimo. Buvo įvertinta žala aplinkai dèl šių teršalų emisijos: amoniakas $\left(\mathrm{NH}_{3}\right)$, nemetaniniai lakieji organiniai junginiai (NMVOC), azoto oksidai

3 lentelè. Nepriklausomybẻ nuo energijos tiekimo iš užsienio [16]

\begin{tabular}{c|c}
\hline Energijos rūšis & Balas \\
\hline Importuojamas kuras & 0 \\
\hline Vietinè nafta & 1 \\
\hline Vietinės gamtinės dujos & 2 \\
\hline Vietinės akmens anglys & 3 \\
\hline Vietinis uranas & 4 \\
\hline Kuro celès & 3 \\
\hline $\begin{array}{c}\text { Vietiniai atsinaujinantieji } \\
\text { energijos ištekliai }\end{array}$ & 5
\end{tabular}


$\left(\mathrm{NO}_{\mathrm{x}}\right)$, kietosios dalelès $(\mathrm{PPM})$, sieros dioksidas $\left(\mathrm{SO}_{2}\right)$. Elektros energijos gamybos technologijų vertinimui šioje atskaitoje panaudotos vidutinès rodiklių reikšmès ES $2020 \mathrm{~m}$.

Išoriniai kaštai dèl poveikio žmoniu sveikatai, išrreikšti $E U R c t / k W h$, atspindi žalą žmogaus sveikatai dèl kietujjų dalelių, dujų ir kitų teršalų emisijos ị atmosferą, vandenị ir dirvožemi. Išoriniai kaštai dèl žalos žmonių sveikatai yra ịvertinti piniginiais vienetais. Žala buvo įvertinta dèl šių teršalų emisijų: amoniakas $\left(\mathrm{NH}_{3}\right)$, nemetaniniai lakieji organiniai junginiai (NMVOC), azoto oksidai (NOx), kietosios dalelès (PPM), sieros dioksidas $\left(\mathrm{SO}_{2}\right)$. Vertinimui panaudotos vidutinès rodikliu reikšmès ES $2020 \mathrm{~m}$.

Radionuklidu išoriniai kaštai, išreikšti EURct / $\mathrm{kWh}$, atspindi žalą žmonių sveikatai dèl radionuklidų emisijos ị atmosferą, vandenį ir dirvožemị. Poveikis žmonių sveikatai dèl radionuklidų emisijos yra išmatuotas piniginiais vienetais. İvertintas šių radionuklidų neigiamas poveikis žmonių sveikatai: aerozoliai, anglis-14; vandenilis-3, tritis, jodas-129, jodas-13, kriptonas-85, inertinès dujos, radonas-222, toris230, uranas-234. Radionuklidų išoriniai kaštai buvo apskaičiuoti ES projektų ExternE [20], NEEDS [16] ir CASES [13] metu. Elektros energijos gamybos technologiju vertinimui šioje atskaitoje panaudotos vidutinès rodiklių reikšmès ES $2020 \mathrm{~m}$.

Socialiniai rodikliai. Pagrindiniai keturi socialiniai rodikliai, parinkti elektros energijos technologijų vertinimui pagal ES energetikos politikos prioritetinius tikslus, yra: technologijų suteikiamos įdarbinimo galimybès, maisto tiekimo rizika, nelaimingi incidentai praeityje ir ateityje.

Technologijos suteikiamos įdarbinimo galimybes (žmogaus metais / $k W h)$. Šis rodiklis yra paremtas darbo jègos, reikalingos $1 \mathrm{kWh}$ elektros energijos pagaminti, îvertinimu. Rodiklis ịvertinamas pagal LCA metodologiją ir atspindi darbo jegos poreiki visoje energijos tiekimo grandineje. PSI parengtoje Ecoinvent duomenų bazèje pateikti LCA darbo jègos îvertinimai 8 elektros energijos tiekimo technologijų grandinems (lignitui, bitumui, akmens anglims, naftai, gamtinèms dujoms, hidro-, vejjo ir saulès energija). Technologinès grandinès apima šiuos komponentus, kuriuose yra ịvertinamas darbo jègos poreikis: 1) kuro gavyba, 2) kuro tiekimas, 3) elektros gamybos jègainès statyba, 4) elektros energijos gamyba, 5) jègainès uždarymas. Elektros energijos gamybos technologijų vertinimui šioje atskaitoje panaudotos vidutinès rodiklių reikšmès ES $2020 \mathrm{~m}$.

Maisto tiekimo rizika, matuojama 0-5 balais, yra kokybinis rodiklis, skirtas įvertinti biomasès panaudojimo elektros energijos gamybai neigiamas pasekmes, susijusias su neigiamu poveikiu maisto tiekimui bei jo kainų augimui. Šis rodiklis buvo pritaikytas CASES [13] ir PLANETS [18] projektuose ir šiuo metu labai aktualus, nes dèl vis daugiau biomasès naudojant energijos, ypač biodegalų, gamybai sparčiai auga maisto kainos.

Nelaimingi incidentai praeityje, išreikšti žmoniu mirtimis / $k W h$. Šis rodiklis parodo fatališkų incidentų riziką, remiantis praeityje įvykusių fatališkų incidentų skaičiumi.
PSI (Paul Shrerer Institute) sukurta duomenų bazè ENSAD (Energy-related Severe Accidents Database), kurioje pateikti visų energijos gamybos technologijų vertinimai pagal nelaimingus atsitikimus praeityje. Šis rodiklis paremtas LCA metodika ir buvo pritaikytas daugelyje ES vykdytų technologijų vertinimo studiju (NEEDS [16], CASES [13], GaBE [19], PLANETS [18]). Elektros energijos gamybos technologijų vertinimui šioje atskaitoje panaudotos vidutinès rodiklių reikšmès ES $2020 \mathrm{~m}$.

Incidentai ateityje yra kokybinis rodiklis, matuojamas $0-5$ balais. Jis atspindi incidento ateityje tikimybę. Kuo aukštesnis yra šis rodiklis, tuo didesné yra incidento galimybė. Šis rodiklis yra nustatytas, atliekant gyventoju apklausas ir nustatant jų požiūrị ị incidento kilimo galimybę specifinę technologiją naudojančioje jègainèje. Šis rodiklis buvo pritaikytas CASES [13], GaBE [19] ir NEEDS [16] projektuose.

\section{INTEGRUOTŲ RODIKLIŲ TAIKYMAS DAUGIAKRITERINĖJE ANALIZĖJE}

Integruoti rodikliai yra formuojami, stengiantis atspindèti pagrindinius rodiklius viename rodiklyje, atliekant ịvairių politikos dokumentų igyvendinimo monitoringą [21]. Ypač svarbi šiuo aspektu yra Darnaus vystymosi strategija, kurioje nustatyta daugelis ekonominių, aplinkosauginių ir socialinių rodikliu, o atliekant jos igyvendinimo monitoringą, būtina ivertinti, kaip šie visi tikslai yra vykdomi. Taip pat tiriant strategijoje numatytų politikos priemonių efektyvumą, būtina ịvertinti šių priemonių poveikị konkretiems iškeltiems tikslams. Integruoti rodikliai parodo tiriamų reiškiniu įvairias svarbias kokybines puses ir šių rodiklių kitimo laike ịtaką bendro integruoto rodiklio kitimui laike. Taigi integruotas darnumo rodiklis atspindi:

- Integruoto rodiklio struktūrinių rodiklių statines charakteristikas ir jų dinamiką retrospektyvos požiūriu;

- Integruoto rodiklio sudedamujjų dalių svorius arba svarbą, tiriant integruoto rodiklio tendencijas;

- Integruoto rodiklio struktūrinių rodiklių tendencijų prognozes;

- Koreliacinius struktūrinių rodiklių tarpusavio ryšius;

- Integruoto rodiklio statinę charakteristiką, dinamiką retrospektyvos požiūriu ir prognozes.

Statines integruoto rodiklio struktūros rodiklių dabartines reikšmes apibrežia naujausių tyrimo metų statistinès struktūros rodiklių reikšmės. Struktūrinių rodiklių dinamiką apibūdina jų laiko eilutès nuo pasirinktų bazinių iki ataskaitinių metų. Struktūrinių rodiklių prognozės yra gaunamos, taikant tiesinés regresijos lygtis, trendams prognozuoti.

Integruotas kompleksinis rodiklis tendencijų tyrimui yra formuojamas indeksų pagalba.

$$
Q_{n}=\sum_{i=1}^{n}\left(w_{i}^{*} Q_{i n}\right)\left(\sum_{i=1}^{n} w_{i}=1\right) ;
$$

čia $Q_{n}$ - integruotas kompleksinis indikatorius laiko momentu $n$, susidedantis iš $i$ rodiklių; 
$Q_{i t}-i$-ojo struktūrinio rodiklio indeksas laiko momentu $n$;

$w_{i}-i$-ojo struktūrinio rodiklio svoris, atspindintis santykinę kiekvieno rodiklio svarbą indikatoriuje.

Integruoto kompleksinio rodiklio sudedamosios dalys (arba struktūrinio rodiklio indeksai) yra apskaičiuojamos kaip indeksai:

$$
Q_{i n}=q_{n i} / q_{o i} ;
$$

čia $Q_{\text {in }}-i$-ojo struktūrinio rodiklio indeksas laikotarpiu $n$;

$q_{n i}-i$-ojo struktūrinio rodiklio reikšmè laikotarpiu $n$;

$q_{o i}-i$-ojo struktūrinio rodiklio reikšmé baziniais metais.

Jeigu formuojant integruotą rodikli ji sudarančių tam tikrų rodiklių reikšmių augimas yra vertinamas kaip teigiamas ir pageidaujamas procesas, tokio rodiklio indekso kitimas nuo 0 iki bet kurių didesnių dydžių turètų žymèti palankų procesą, o rodiklių, kurių mažèjimas yra pageidaujamas procesas, indeksai yra perskaičiuojami:

$$
Q_{i n}=1 / Q_{i n} .
$$

Taip rodikliai igyja lyginimui tinkamų balų turinị ir leidžia analizuoti integruoto rodiklio augimą, kaip pageidaujamą procesą.

Tuo tarpu politikos priemonių, energijos gamybos technologijų bei energetikos plètros scenarijų daugiakriterinis vertinimas gali büti atliekamas formuojant integruotus energetikos plètros scenarijų, energijos gamybos technologijų bei politikos priemonių vertinimo rodiklius, sudarytus iš atskirų rodiklių, atspindinčiu energetikos sektoriaus plètros prioritetinius tikslus, skirtus politikos priemonei, energetikos plètros scenarijui ar energijos gamybos technologijai ivvertinti.

Politikos priemonès ar energetikos plètros scenarijaus ịtaka tam tikram rodikliui gali būti nustatoma modeliavimo pagalba, taikant Bendrosios pusiausvyros arba Dalinès pusiausvyros energetikos sektoriaus plètros modelius. Pavyzdžiui, tiriant anglies dvideginio mokesčio arba žaliųjų sertifikatų ịvedimo efektyvumą, modeliavimo pagalba sudarant atskirus scenarijus, nustatoma tokio mokesčio bei žaliujjų sertifikatų sistemos įtaka šiltnamio dujų emisijų, energijos intensyvumo sumažèjimui, atsinaujinančiųjų energijos išteklių panaudojimo, energijos kainų, energijos importo augimui ir kitiems svarbiems tikslams. Parenkant tinkamiausius energetikos sektoriaus plètros scenarijus, modeliavimo pagalba gauti duomenys vartojami aptartiesiems rodikliams - šiltnamio dujų emisijų sumažèjimas, energijos intensyvumo sumažèjimas, atsinaujinančiųjų energijos išteklių panaudojimo išaugimas, energijos importo sumažèjimas ir kt. - apskaičiuoti. Visi šie svarbūs kriterijai gali būti struktūriniais rodikliais, sudarančiais integruotą rodikli, pagal kurị lyginamos politikos priemonès ir energetikos sektoriaus plètros scenarijai. Energijos gamybos technologijos taip pat yra lyginamos, apskaičiuojant integruotą rodiklį, kurị sudaro tokie svarbūs struktūriniai rodikliai, kaip šiltnamio dujų emisijos (kWh), elektros energijos gamybos kaštai ir kt.
Integruotą politikos priemonès, energetikos sektoriaus plètros scenarijaus ar energijos gamybos technologijos daugiakriterinio vertinimo rodiklị sudaro pagrindinių struktūrinių rodiklių nuokrypio nuo vidurkio suma. Toks integruotas politikos priemonès efektyvumo vertinimo rodiklis yra formuojamas alternatyviu politikos priemonių, energetikos sektoriaus plètros scenariju ar energijos gamybos technologijų palyginimui, o ne tendencijų analizei, kaip integruotas rodiklis, skirtas strategijų ir programų monitoringui:

$$
Q_{j}=\sum_{i=1}^{n}\left(w_{i} \cdot Q_{i j}\right), \sum_{i=1}^{n} w_{i}=1 ;
$$

čia $Q_{j}$ - integruotas kompleksinis rodiklis priemonei (scenarijui, technologijai), susidedantis iš $i$ rodiklių;

$Q_{i j}$ - $i$-ojo struktūrinio rodiklio indeksas priemonei (scenarijui, technologijai) $j$;

$w_{i}-i$-ojo struktūrinio rodiklio svoris, atspindintis santykinę kiekvieno rodiklio svarbą integruotame rodiklyje.

Rodiklio nuokrypis arba indeksas nuo vidurkio apskaičiuojamas:

$$
Q_{i j}=q_{i j} / q i_{v i d} ;
$$

čia $Q_{i j}$ - i-ojo struktūrinio rodiklio indekso reikšmé priemonei (scenarijui, technologijai) $j$;

$q_{i j}-i$-ojo struktūrinio rodiklio reikšmè priemonei (scenarijui, technologijai) $j$;

$q i_{\text {vid }}-i$-ojo struktūrinio rodiklio reikšmių visoms priemonèms (scenarijams, technologijoms) vidurkis.

Analogiškai kaip integruotų tendencijų tyrimo rodiklių atveju, jeigu formuojant integruotą rodiklị ji sudarančiu rodiklių reikšmių augimas yra vertinamas kaip teigiamas ir pageidaujamas procesas, tokio rodiklio indekso kitimas nuo 0 iki bet kurių didesnių dydžiu turètų žymèti palankų procesą arba kokybès augimą, o rodiklių, kurių mažèjimas yra pageidaujamas procesas, indeksai yra perskaičiuojami pagal (6) formulę:

$$
Q_{i j}=1 / Q_{i j}
$$

Aprašytas integruotų rodiklių metodas gali būti nesunkiai pritaikytas aplinkos apsaugos politikos priemonių, energetikos sektoriaus plètros scenarijų, energijos gamybos technologiju vertinimui bei Nacionalinès energetikos plètros strategijos monitoringui.

\section{ELEKTROS ENERGIJOS GAMYBOS TECHNOLOGIJŲ DARNUMO VERTINIMAS}

Pagrindinès elektros energijos gamybos technologijos, numatomos taikyti $2020 \mathrm{~m}$., pateiktos 4 lenteleje. Šis technologijų sąrašas yra sudarytas, remiantis kitose ES atliktose studijose, skirtose ateities elektros energijos gamybos technologiju analizei, pateiktais elektros energijos gamybos technologijų aprašymais. 
4 lentelè. Elektros energijos gamybos technologijos [13]

\begin{tabular}{|c|c|c|}
\hline \multicolumn{3}{|c|}{ Technologijos ir kuras elektros energijos gamybai } \\
\hline \multirow{2}{*}{ Branduolinis kuras } & & EPR \\
\hline & & PBMR \\
\hline \multirow{11}{*}{ Organinis kuras } & \multirow{2}{*}{ nafta } & Kondensacinè jėgainė \\
\hline & & Dujų turbina \\
\hline & \multirow{3}{*}{ anglys } & Kondensacinè jėgainè \\
\hline & & Integruoto dujofikavimo kombinuotojo ciklo jègainè (IDKC) \\
\hline & & IDKC su anglies dioksido atskyrimu ir saugojimu (AAS) \\
\hline & \multirow{3}{*}{ lignitas } & Kondensacinè jėgainè \\
\hline & & IDKC \\
\hline & & IDKC su AAS \\
\hline & \multirow{3}{*}{$\begin{array}{l}\text { gamtinès } \\
\text { dujos }\end{array}$} & Kombinuotojo ciklo jėgainė \\
\hline & & Kombinuotojo ciklo jėgainè su AAS \\
\hline & & Dujų turbina \\
\hline \multirow{6}{*}{ Hidroenergija } & \multirow{3}{*}{ derivacinè } & $<10 \mathrm{MW}$ \\
\hline & & $<100 \mathrm{MW}$ \\
\hline & & $>100 \mathrm{MW}$ \\
\hline & vagos & \\
\hline & hidroakumu & \\
\hline & bangų & \\
\hline \multirow{2}{*}{ Vèjo energija } & krante & \\
\hline & jūroje & \\
\hline \multirow{2}{*}{ Saulès fotoelektra } & stogas & \\
\hline & atvira erdvė & \\
\hline \multicolumn{3}{|l|}{ Saulès šiluma } \\
\hline \multicolumn{3}{|l|}{ Termofikacinès jègainès } \\
\hline \multirow{4}{*}{$\begin{array}{l}\text { Termofikacinè jègainè su } \\
\text { kondensacine garo turbina }\end{array}$} & \multirow{2}{*}{$\begin{array}{l}\text { Gamtinès } \\
\text { dujos }\end{array}$} & Kombinuotojo ciklo dujų turbina (KCDT) \\
\hline & & KCDT su anglies dioksido atskyrimu ir saugojimu (AAS) \\
\hline & \multirow{2}{*}{ Anglys } & IDKC \\
\hline & & IDKC su anglies dioksido atskyrimu ir saugojimu (AAS) \\
\hline \multirow{2}{*}{$\begin{array}{l}\text { Termofikacinè jègainè su } \\
\text { priešslègine garo turbina }\end{array}$} & \multicolumn{2}{|c|}{ Gamtinès dujos } \\
\hline & \multicolumn{2}{|l|}{ Anglys } \\
\hline \multirow{2}{*}{$\begin{array}{l}\text { Biomasės termofikacinè jègainè su } \\
\text { kondensacine garo turbina }\end{array}$} & \multicolumn{2}{|l|}{ Šiaudai } \\
\hline & \multicolumn{2}{|c|}{ Medienos granulès } \\
\hline \multirow{3}{*}{ Kuro elementai } & \multirow{2}{*}{$\begin{array}{l}\text { Gamtinès } \\
\text { dujos }\end{array}$} & Lydytų karbonatų kuro elementai \\
\hline & & Kietakūnio oksido kuro elementai \\
\hline & Biodujos & Lydytų karbonatų kuro elementai \\
\hline
\end{tabular}

Elektros energijos gamybos technologijos buvo ịvertintos pagal 13 rodiklių rezultatus. Šie 13 rodiklių susideda iš 5 ekonominių rodiklių (privatūs kaštai, tinklo kaštai, apkrovos veiksnys, atsakas ị pikinę apkrovą ir tiekimo saugumas), 4 aplinkosauginių rodiklių (išoriniai aplinkosauginiai kaštai, radionuklidų išoriniai kaštai, poveikio žmogaus sveikatai išoriniai kaštai, ŠD emisijos) ir 4 socialinių rodiklių (technologijų suteikiamos įdarbinimo galimybès, maisto tiekimo rizika, incidentai praeityje bei incidentai ateityje). Visi rodiklių įvertinimai pateikti $2020 \mathrm{~m}$. bei taikomi ES vidutiniai duomenys.

Kadangi svariais ekonominiais rodikliais pasižyminčioms technologijoms ne visada būdingi aukšti aplinkosauginiai ir socialiniai rodikliai, o atvirkščiai, todèl siekiant nustatyti geriausiai ES energetikos politikos tikslus atitinkančias elektros energijos technologijas, būtina atlikti daugiakriterinę analizę. Ją atliksime taikydami integruotų darnumo rodiklių metodą. Integruotas technologijų darnumo indikatorius kiekvienai technologijai yra apskaičiuojamas, taikant (3) formulę. Kuo mažesnis darnumo indikatorius, tuo geriau elektros energijos gamybos technologija atitinka ES energetikos politikos tikslus.

Jeigu vertinant elektros energijos gamybos technologijas rodiklio didejimas (vidutinis apkrovos veiksnys, atsakas i pikinę apkrovą, tiekimo saugumas, užimtumas) yra vertinamas kaip teigiamas, taikoma (4) formulè. Tuo tarpu jeigu pageidaujamas yra rodiklio mažèjimas (privatūs kaštai, prijungimo prie tinklo kaštai, poveikis žmogaus sveikatai, aplinkosauginiai išoriniai kaštai, radionuklidų išoriniai kaštai, ŠD emisijos, incidentai praeityje bei incidentai ateityje), taikoma (5) formulè. Integruotą darnumo rodikli kiekvienai technologijai sudaro 13 struktūrinių rodiklių, pateiktų 1 lentelèje.

Siekiant atlikti jautrumo analizę, nes nebuvo atlikta ekspertų apklausa rodiklių svoriams nustatyti, elektros energijos gamybos technologijų darnumas bus vertinamas taikant 
keturis vertinimo scenarijus, skirtus nustatyti, kaip aplinkosauginių, ekonominių ir socialinių rodiklių svorio keitimas veikia elektros energijos gamybos technologijų rangavimo rezultatus. Atlikti tokie elektros energijos gamybos technologijų rangavimo scenarijai:

1) Scenarijus, kai visiems rodikliams integruotame indikatoriuje suteikiamas vienodas svoris;

2) I aplinkosauginius rodiklius orientuotas scenarijus: aplinkosauginiams rodikliams suteiktas $80 \%$ svoris, o ekonominiams ir socialiniams rodikliams - po $10 \%$;
3) I ekonominius rodiklius orientuotas scenarijus: ekonominiams rodikliams suteiktas $80 \%$ svoris, o aplinkosauginiams ir socialiniams rodikliams - po $10 \%$;

4) I socialinius rodiklius orientuotas scenarijus: socialiniams rodikliams suteiktas $80 \%$ svoris, o ekonominiams ir aplinkosauginiams rodikliams - po $10 \%$.

1 pav. parodytas elektros energijos gamybos technologijų rangavimas pagal pirmą scenarijų, ekonominiams, socialiniams ir aplinkosauginiams kriterijams suteikus vienodus svorius.

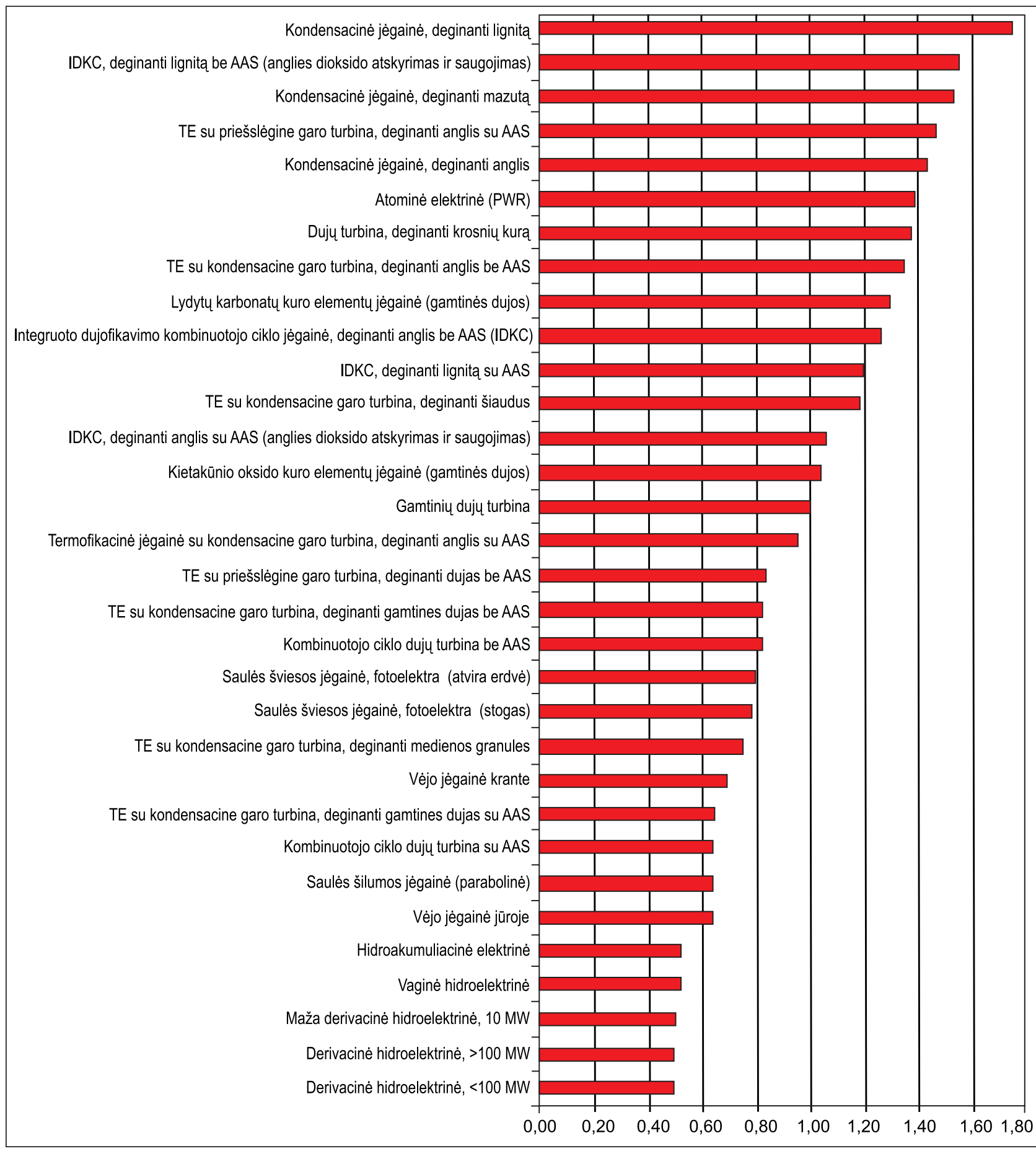

1 pav. Elektros energijos gamybos technologijų rangavimas pagal 1-aji scenarijų (1 lentelëje pateiktiems rodikliams suteiktas vienodas svoris) 
Kaip matyti iš 1 pav. pavaizduotų duomenų, geriausiai ES energetikos politikos tikslus atspindinčios technologijos yra paremtos atsinaujinančiaisiais energijos ištekliais, o blogiausiai - deginamomis anglimis. Tai yra susiję su dideliais šių elektrinių išoriniais aplinkosauginiais ir žmonių sveikatos kaštais.

2 pav. parodytas elektros energijos gamybos technologijų rangavimas pagal antrąji (aplinkosauginị) rangavimo scenarijų, kai 4 aplinkosauginiams rodikliams, pateiktiems 4 lenteleje, suteiktas $80 \%$ svoris (arba po $20 \%$ kiekvienam aplinkosauginiam rodikliui), o ekonominiams bei socialiniams rodikliams suteiktas $20 \%$ svoris (po $10 \%$ kiekvienai rodiklių grupei).

Kaip matyti iš 2 pav. pateiktų duomenų, aplinkosauginio scenarijaus atveju gauti panašūs rezultatai, kaip ir pirmojo scenarijaus, kai visiems rodikliams taikomi vienodi svoriai:

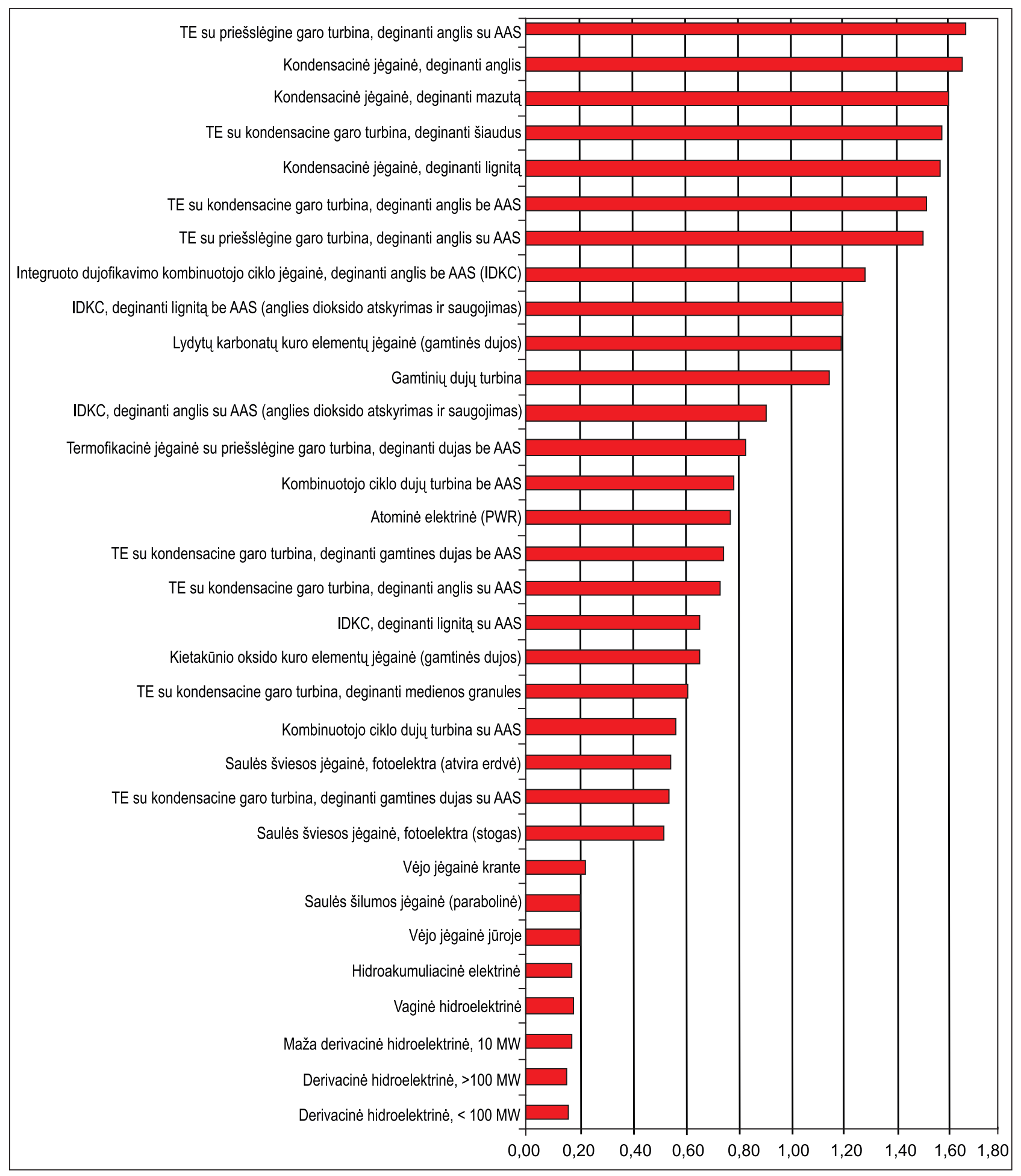

2 pav. Elektros energijos gamybos technologijos rangavimas pagal 2-aji (aplinkosauginį) scenarijų 
geriausios technologijos yra paremtos atsinaujinančiaisiais energijos ištekliais, o blogiausios pagal ES energetikos politikos tikslų atitikimą yra technologijos, naudojančios akmens anglis. Tai patvirtina anksčiau pateiktą pastabą, kad aplinkosauginių rodiklių poveikis nusveria kitų rodiklių poveikį ranguojant elektros energijos gamybos technologijas.
Elektros energijos gamybos technologiju rangavimas pagal trečiajji (ekonominị) scenarijų parodytas 3 pav. Pagal ši scenarijų, 5 ekonominiams elektros energijos gamybos technologijų vertinimo rodikliams yra suteiktas $80 \%$ svoris, tuo tarpu visiems kitiems socialiniams ir aplinkosauginiams rodikliams vienodai paskirstytas $20 \%$ svoris integruotame technologijų darnumo vertinimo indikatoriuje.

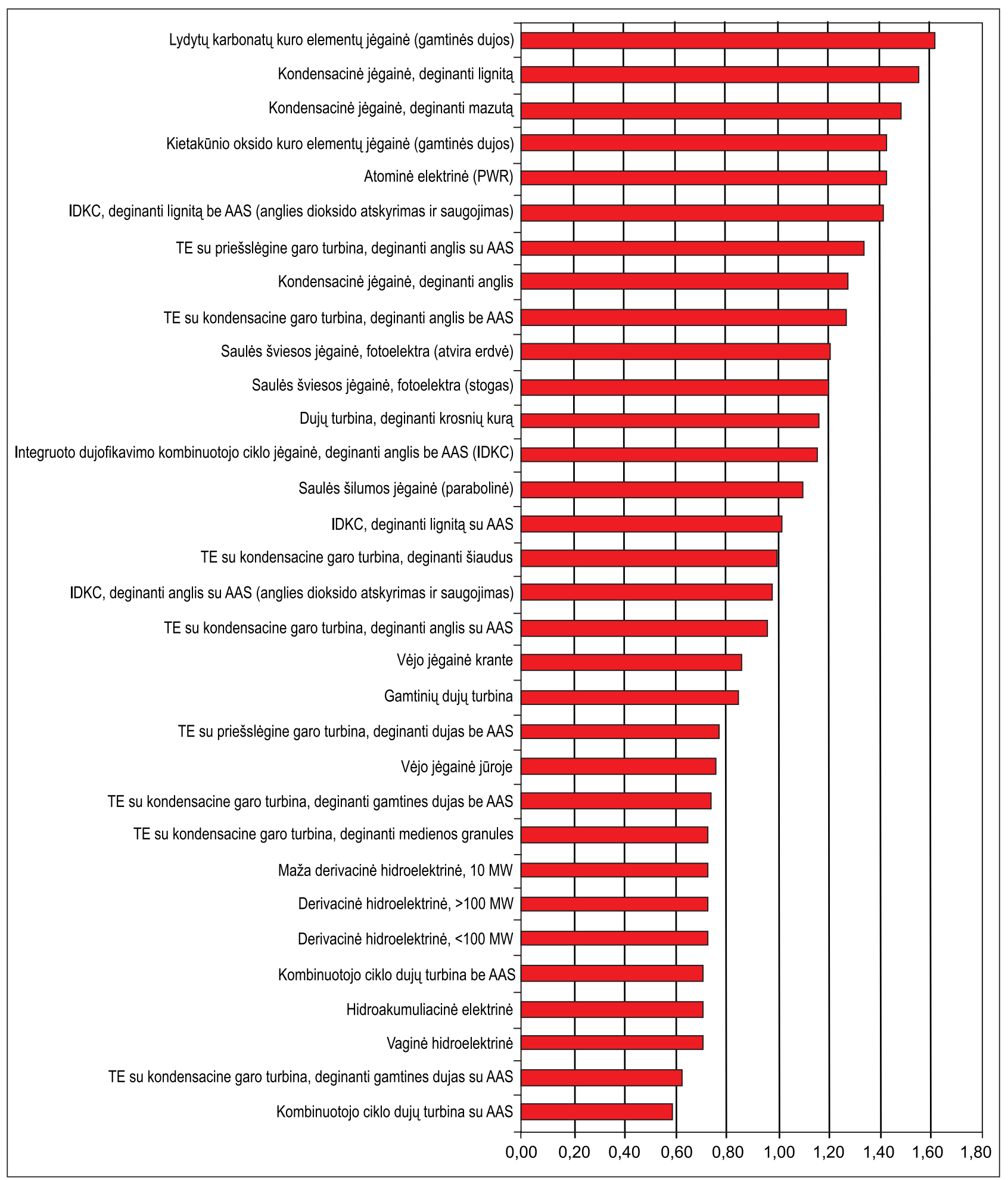

3 pav. Elektros energijos gamybos technologijos rangavimas pagal 3-iaji (ekonominį) scenarijų 
Kaip matyti iš 3 pav. pateiktų duomenų, geriausiai ES energetikos politikos tikslus atitinkančios technologijos yra kombinuotojo ciklo jėgainès, deginančios gamtines dujas. Blogiausios technologijos yra kuro elementų bei kondensacinè jègainès, deginančios lignitą ir mazutą. Tai yra susiję su aukštais naujų elektros energijos gamybos technologijų, naudojančių kuro elementus, kaštais.
Elektros energijos gamybos technologiju rangavimas pagal 4-ajji (socialinį) scenarijų yra parodytas 4 paveiksle. Pagal ši scenarijų 4 socialiniams rodikliams yra suteiktas $80 \%$ svoris, o likusiems ekonominiams ir aplinkosauginiams rodikliams vienodai paskirstytas $20 \%$ svoris.

Kaip matyti iš 4 pav. parodytų duomenų, geriausiai ES energetikos politikos tikslus atitinkančios yra saulès ir

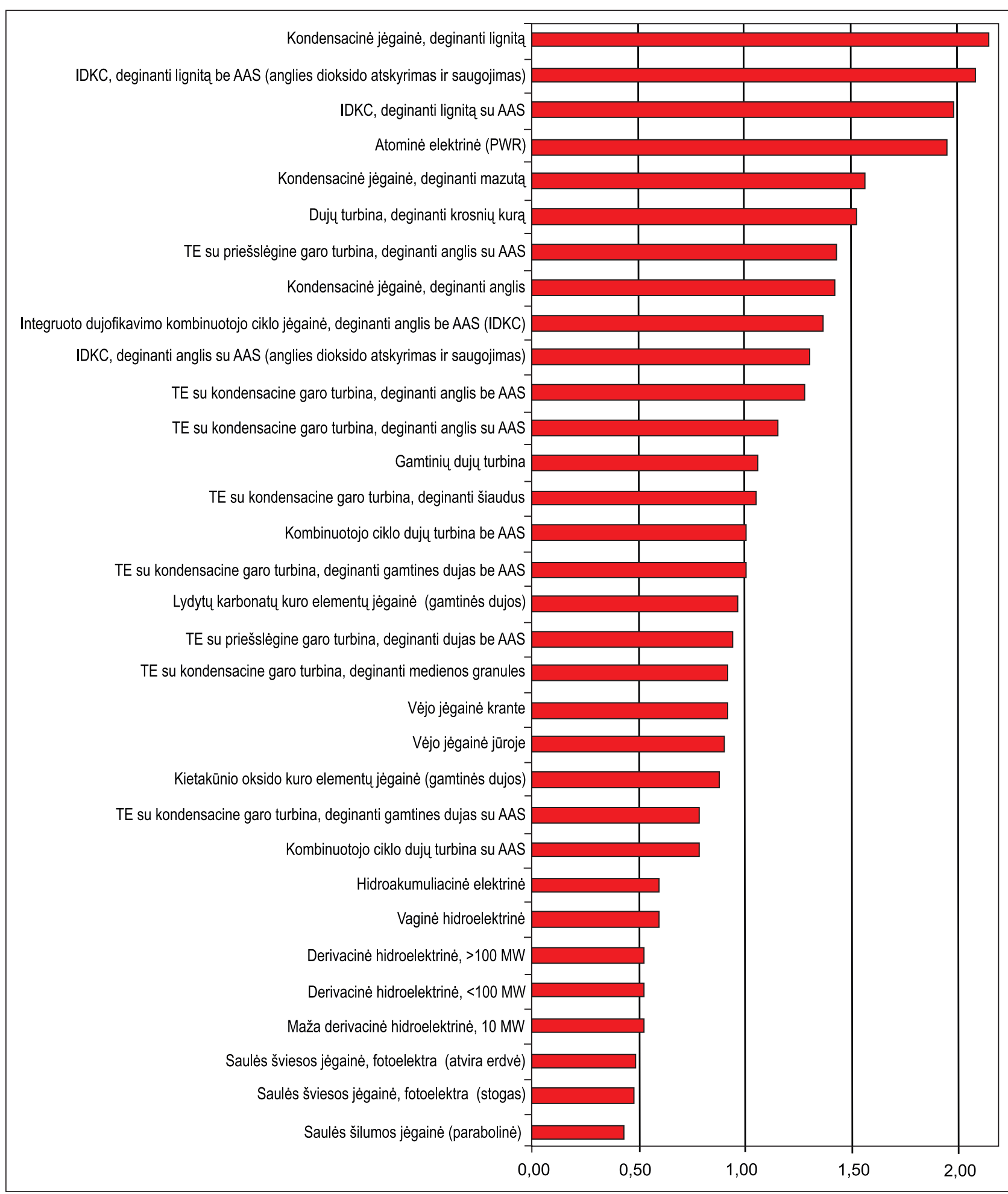

4 pav. Elektros energijos gamybos technologijos rangavimas pagal 4-aji (socialinį) scenariju 
hidrojègainès, o blogiausiai - lignitą ir anglis deginančios jègainès. Kadangi saulès ir hidroelektrinès rezultatai yra teigiami, susiję su įdarbinimo galimybemis, šios technologijos pagal socialinị scenarijų yra vertinamos geriausiai.

\section{IŠVADOS}

1. Elektros energijos gamybos technologijų vertinimas ir rangavimas pagal rodiklius, nustatytus remiantis ES energetikos politikos prioritetais taikant ịvairius rangavimo scenarijus ir keičiant rodiklių svorị integruotame darnumo indikatoriuje, parodè, kad geriausios technologijos yra paremtos atsinaujinančiụjų energijos išteklių naudojimu, o blogiausios, paremtos akmens anglių bei lignito naudojimu. Kai kurių rangavimo scenarijų rezultatai apibendrinti toliau.

2. Elektros energijos gamybos technologiju rangavimo pagal darnumo kriterijus scenarijaus, kai visiems darnumo rodikliams buvo suteiktas vienodas svoris, atveju geriausia technologija yra hidrojègainès, o blogiausia - kondensacinès ir IDCK be AAS, deginančios lignitą, bei kondensacinès jeggainès, deginančios mazutą.

3. Ekonominio scenarijaus atveju geriausios elektros energijos gamybos technologijos yra kombinuotojo ciklo ir TE jègainès, deginančios gamtines dujas. Po to seka hidrojègainès. Blogiausios technologijos pagal ši scenarijų yra kuro elementais pagrịstos technologijos. Po jų seka kondensacinès jègainès, deginančios lignitą ir mazutą.

4. Aplinkosauginio scenarijaus atveju geriausios technologijos yra hidroelektrinès, vejo ir saulès jègainès, o blogiausios technologijos - akmens anglis deginančios kondensacinès bei termofikacinès jègainès.

5. Socialinio scenarijaus atveju geriausia elektros energijos gamybos technologija yra saulès, po to seka hidrojègainés. Blogiausios technologijos - kondensacinè jègainé, deginanti lignitą, ir IDCK, deginanti lignitą be AAS.

Tyrimą finansuoja Lietuvos mokslo taryba (sutarties Nr. ATE-01/2011)

Gauta 20110516 Priimta 20110622

\section{Literatūra}

1. Roy B. Multicriteria Methodology for Decision Aiding. Dordrecht: Kluwer Academic Publishers, 1996.

2. Siskos J., Hubert Ph. Multicriteria analysis of the impacts of energy alternatives: A survey and a new comparative approach. European Journal of Operational Research. 1983. N 13. P. $278-299$.

3. Güngör Z., Arikan F. A fuzzy outranking method in energy policy planning. Fuzzy Sets and Systems. 2000. N 114. P. 115-122.

4. Hämäaläainen R., Karjaläinen R. Decision support forrisk analysis in energy policy. European Journal of Operational Research. 1992. N 56. P. 172-183.
5. Hämäläinen R. A decision aid in the public debate on nuclear power. European Journal of Operational Research. 1990. N 48. P. 66-76.

6. Hämäläinen R., Seppäläinen T. The Analytic Network Process in energy policy planning. Socio-Economic Planning Science. 1986. N 20. P. 399-405.

7. Beccali M, Cellura M., Ardente D. Decision making in energy planning: The ELECTRE multicriteria analysis approach compared to a fuzzy-sets methodology. Energy Conversion Management. 1998. N 39. P. 1869-1881.

8. Akash B., Al-Jayyousi O., Mohsen M. Multicriteria analysis of nonconventional energy technologies for water desalination in Jordan. Desalination. 1997. N 114. P. 1-12.

9. Kablan M. Prioritization of decentralized electricity options available for rural areas in Jordan. Energy Conversion Management. 1997. N 38. P. 1515-1521.

10. Mamlook R., Akash B., Nijmeh S. Fuzzy sets programming to perform evaluation of solar systems in Jordan. Energy Conversion Management. 2001. N 42. P. 1717-1726.

11. Ness B., Urbel-Piirsalu E., Anderberg S., Olsson L. Categorising tools for sustainability assessment. Ecological Economics. 2007. N 3. P. 498-508.

12. EU FM 6 Project. EUSUSTEL. European Sustainable Electricity; Comprehensive Analysis of Future European Demand and Generation of European Electricity and Its Security of Supply. Final technical report, 2007.

13. EU FM 6 Project. CASES. Cost Assessment of Sustainable Energy System. Development of a set of full cost estimates of the use of different energy sources and its comparative assessment in EU countries, 2008.

14. EU FM 6 Project. CASES. Cost Assessment of Sustainable Energy System. Report on Policy Instruments Assessment Methods and Comparative Analyses, 2008.

15. EU FM 7 Project. NEEDS. New Energy Externalities Developments for Sustainability. Survey of criteria and indicators, 2005.

16. EU FM 7 Project. NEEDS. New Energy Externalities Developments for Sustainability. Final Report on Technology Foresight Method, 2006.

17. EU FM 7 Project. NEEDS. New Energy Externalities Developments for Sustainability. Environmental, economic and social criteria and indicators for sustainability assessment of energy technologies, 2007.

18. EU FM 7 Project. PLANETS. Report on Technology Assessment-II, 2009.

19. Hirschberg S., Dones R., Heck T., Burgherr P., Schenler W., Bauer C. Sustainability of Electricity Supply Technologies under German Conditions: A Comparative Evaluation. GaBE. PSI-Report No. 04-15. Villigen: Paul Scherrer Institut, Switzerland, 2004.

20. European Commission. ExternE - Externalities of Energy. Vol. 7. Methodology 1998 Update. Luxemburg, 1999.

21. Štreimikienè D., Mikalauskienė A. Integruotų rodiklių taikymas Nacionalinès energetikos strategijos monitoringui. Energetika. 2009. T. 55. Nr. 3. P. 158-167. 
Dalia Štreimikienè, Asta Mikalauskienè, Jūratè Zaikienė

SUSTAINABILITY ASSESSMENT OF ELECTRICITY GENERATION TECHNOLOGIES IN THE EU BY APPLYING INTEGRATED INDICATORS

Sum mary

The paper deals with the sustainability assessment of electricity generation technologies in the EU, which was performed by applying the multi-criteria analysis approach. Integrated indicators for sustainability assessment of electricity generation technologies were calculated for specific technologies. These integrated indicators were obtained by summing up the normalized social, economic and environmental indicators for specific electricity generation technologies. The electricity generation technologies were ranked according to their positive impact on sustainable energy development in the EU, based on these integrated indicators. Sustainability assessment indicators for specific technologies were evaluated by applying results of empirical studies conducted in the EU. The sustainability assessment performed in the present study has indicated that the best technologies in terms of sustainability in the energy sector are technologies based on renewables.

Key words: electricity generation technologies, sustainability assessment, ranking
Даля Штреймикене, Аста Микалаускене,

Юрате Зайкене

\section{ОЦЕНКА УСТОЙЧИВОСТИ ТЕХНОЛОГИЙ ПРОИЗВОДСТВА ЭЛЕКТРОЭНЕРГИИ В ЕС ПРИ ПРИМЕНЕНИИ КОМПЛЕКСНЫХ ПОКАЗАТЕЛЕЙ}

Резюме

В статье рассматривается устойчивость технологий производства электроэнергии в ЕС. Эта устойчивость оценивается путем многокритерного анализа. Комплексные интегрированные показатели для оценки устойчивости технологий производства электроэнергии были рассчитаны для конкретных технологий. Значения показателей были получены суммированием нормированных социальных, экономических и экологических показателей для конкретных технологий производства электроэнергии. Технологии производства электроэнергии были ранжированы по их позитивному влиянию на устойчивое развитие энергетики в ЕС, исходя из этих интегрированных показателей. Показатели энергетической устойчивости конкретных технологий были оценены по результатам эмпирических исследований, проведенных в ЕС. Анализ устойчивости показал, что лучшие технологии с точки зрения устойчивости в энергетическом секторе - технологии, основанные на возобновляющихся источниках.

Ключевые слова: технологии производства электроэнергии, оценка устойчивости, рейтинг 